Note

\title{
Characterization of type and genetic diversity among soybean cyst nematode
} differentiators

\author{
Éder Matsuo ${ }^{1}$, Tuneo Sediyama ${ }^{*}$, Rosângela D’Arc de Lima Oliveira², Cosme Damião Cruz ${ }^{3}$, Rita de Cássia Teixeira Oliveira ${ }^{4}$
}

IUFV/CCA - Depto. de Fitotecnia, Av. Peter Henry Rolfs, s/n

- Campus Universitário - 36570-000 - Viçosa, MG - Brasil.

2UFV/CCA - Depto. de Fitopatologia.

3UFV/CCB - Depto. de Biologia Geral.

${ }^{4}$ Bacuri Pesquisa e Melhoramento, R. Aimorés, 290 -

36570-000 - Viçosa, MG - Brasil.

*Corresponding author <tuneo@ufv.br>

Edited by: Cláudio Marcelo Gonçalves de Oliveira

Received February 25, 2011

Accepted October 14, 2011
ABSTRACT: The development of soybean cyst nematode, Heterodera glycines Ichinohe, resistant genotypes with high yields has been one of the objectives of soybean (Glycine max (L.) Merrill) breeding programs. The objective of this study was to characterize the pathotype of soybean cyst nematodes and analyze the genetic diversity of ten differentiator lines ('Lee 74', Peking, Pickett, PI 88788, PI 90763, PI 437654, PI 209332, PI 89772, PI 548316 and 'Hartwig'). Inoculum was obtained from plants cultivated in field soil in Viçosa, state of Minas Gerais, Brazil. Thirty-four days after inoculating each plant with 4,000 eggs, the number of females, female index, total number of eggs, number of eggs per female, reproduction factor, plant height, number of nodes, fresh and dry matter weights were assessed. The differential lines were first grouped with Scott-Knott test. Subsequently, the genetic diversity was evaluated using dendrograms, graphic analysis and the Tocher grouping method. The inoculum of H. glycines obtained from NBSGBP-UFV was characterized as HG Type 0. The differentiating lines were divergent, and PI 89772, PI 437654, 'Hartwig' and 'Peking' had the greatest potential for use in breeding programs.

Keywords: Glycine max, Heterodera glycines, soybean breeding, resistant cultivars

\section{Introduction}

The soybean cyst nematode (SCN), Heterodera glycines Ichinohe, was detected in Brazil for the first time in the 1991/1992 growing season (Lima et al., 1992; Lordello et al., 1992; Monteiro and Moraes, 1992). It is currently present in ten Brazilian states, in an estimated area of over 2.0 million hectares (EMBRAPA, 2008). The grain yield losses in these locations can reach $90 \%$, depending on the degree of infestation, cultivar susceptibility, soil fertility and nematode race (Dhingra et al., 2009).

Control strategies include crop rotation, use of resistant soybean (Glycine max (L.) Merrill) cultivars, and the combination of these methods has been shown to be adequate (EMBRAPA, 2008). Several studies have endeavored to identify cultivars with SCN resistance in breeding programs (Dias et al., 2009).

In addition to the seven differential lines used to characterize pathogenic variability of SCN (Niblack et al., 2006), genotypes used periodically as resistance sources in breeding programs can be included to assess their potential to increase resistance (Niblack et al., 2006). The success of a breeding program is enhanced by the inclusion of genetic variability in the working population (Cruz and Carneiro, 2006). In plant breeding, studies to estimate genetic diversity has been made as of Matsuo et al. (2009) in soybean; Conde et al. (2011) in wheat and Leão et al. (2011) in grape.

The objective of this study was to characterize the HG type of our SCN populations, and to analyze the genetic diversity among the differentiating lines.

\section{Materials and Methods}

The experiment was conducted in a greenhouse in Viçosa, Minas Gerais State, Brazil $\left(20^{\circ} 45^{\prime} 14^{\prime \prime}\right.$ S; $42^{\circ} 52^{\prime} 54^{\prime \prime} \mathrm{W}$; $649 \mathrm{~m}$ a.s.1.). A randomized complete design with six replications was used and the experimental unit consisted of one plant. During the experiment, the average temperature was $27.7^{\circ} \mathrm{C}$.

Infested soil with $H$. glycines was collected from the Nematode Bank of the Soybean Genetic Breeding Program at the Universidade Federal de Viçosa, (NBSGBP-UFV). The Nematode Bank was formed in 1996 from field soil collected from different Brazilian areas cropped with soybean. To maintain the SCN sample in the NBSGBP-UFV, a susceptible soybean cultivar was planted at least twice a year. Soybean cultivar was usually grown 'FT-Estrela'. Among the different sample present in the NBSGBP-UFV, were used those previously characterized as race 3 in 1998 by Silva et al. (1999c).

The cyst nematode was multiplied from $3 \mathrm{dm}^{3}$ soil from each sample of the NBSGBP-UFV that were homogenized and distributed in the pots. The soil from each sample, after 34 days with susceptible soybean plants, was mixed between the different samples, race 3 , used in this study, which resulted in an infested homogeneous soil. This SCN was maintained in a greenhouse using the susceptible soybean cultivar 'Quartzo'.

To obtain the eggs, the plants were removed from the pots and the root systems placed in a $0.84 \mathrm{~mm}(20$ mesh) over $0.15 \mathrm{~mm}$ (100 mesh) pore sieves, and then washed with a strong jet of running water. The females 
retained in the $0.15 \mathrm{~mm}$ (100 mesh) pore sieve were transferred to a $0.15 \mathrm{~mm}$ (100 mesh) over $0.025 \mathrm{~mm}$ (500 mesh) pore sieve where they were squashed. The eggs retained in the $0.025 \mathrm{~mm}$ (500 mesh) pore sieve were transferred to a beaker for later quantification by microscope. The eggs concentration was determined by counting in a Peters counting chamber and the suspension standardized to 1,000 eggs $\mathrm{mL}^{-1}$.

The differentiating lines seeds 'Peking', 'Pickett' 'PI 88788, PI 90763, PI 437654, PI 209332, PI 89772, PI 548316 and 'Hartwig' plus 'Lee 74' (susceptible standard), provided by Embrapa Soja, were germinated in a sand bed previously sterilized with methyl bromide. At the VE stage (Fehr and Caviness, 1977), the plants were standardized (by size and vigor) and transplanted to ceramic pots containing $0.8 \mathrm{dm}^{3}$ of sand and clay soil (55 $\%: 21 \%: 24 \%$ of sand:silt:clay) mixture (1:1) (v/v) that had been sterilized with methyl bromide.

Each pot received 4,000 eggs ten days after planting, distributed in four $2 \mathrm{~cm}$ deep holes in the soil made with a glass rod, $2 \mathrm{~cm}$ from the main stem.

The root system of each inoculated plant was removed from the soil 34 days after inoculation and washed under a strong jet of running water in $0.84 \mathrm{~mm}$ (20 mesh) pore sieves attached to another $0.09 \mathrm{~mm}$ (160 mesh) pore sieves. Females retained in the $0.09 \mathrm{~mm}$ (160 mesh) pore sieves were collected with water in a beaker and counted in a plastic counting plate with a grid base under a stereoscopic microscope (20X). The female index (FI) was used to determine the race in the sample (Riggs and Schmitt, 1988; Dias et al., 1998) and to HG Type characterization according to Niblack et al. (2002). In addition to the number of females, number of eggs, number of eggs per female, reproduction factor (Oostenbrink, 1966), the plant height, number of nodes, fresh and dry matter weight were also assessed.

Number of females, number of eggs and number of eggs per female were transformed in $\sqrt{(x+1)}$ before analysis of variance and the means of all the traits assessed, except for the reproduction factor, were grouped by the Scott-Knott test $(p<0.05)$. The differential lines were later analyzed for genetic diversity based on the traits related to resistance (number of females, number of eggs and number of eggs per female) and agronomic traits (plant height, number of nodes, fresh and dry matter weights). The dissimilarity among the hosts was estimated by the Mahlanobis distance. The genetic diversity was studied by a dendrogram using UPGMA (Unweighted Pair Group Method with Arithmetic Mean), graphic analysis following the canonic variables and differentiating lines were grouped by the Tocher optimization method. The statistical analyses were performed by the Programa Genes: Estatística experimental e matrizes (Cruz, 2006) and Programa Genes: Diversidade Genética (Cruz, 2008).

\section{Results and Discussion}

The female indices were $6.4,1.9,1.1,1.0$, and 0.0 $\%$, respectively to 'Pickett', 'Peking', PI88788, PI90763, and 'Hartwig'. Thus, the inoculum from the NBSGBPUFV was confirmed as belonging to race 3 (Riggs and Schmitt, 1988). In the HG Type characterization of this inoculum (Niblack et al., 2002) a female index (FI) of less than $10 \%$ was obtained for all indicator lines, showing that the isolate was a Type 0 (zero) (Table 1).

The SCN population from the NBSGBP-UFV was first characterized as race 3 (Silva et al., 1999c). $H$. glycines is a species with amphmitic reproduction where the females can attract and be fertilized by more than one male. This can result in genetic variability in the soybean cyst nematode population in the field (Triantaphyllou and Esbenshade, 1990). The use of resistant cultivars is the most economic and popular control method used by the producers (Dias et al., 2009). However, over time changes in the physiological race may occur due to selection pressure (Triantaphyllou, 1975; Schmitt and Noel, 1984; Santana et al., 2009). Our results were similar to those as Silva et al. (1999a,b).

In the soybean cyst nematode HG type classification system, 'Lee 74 ' was used as susceptible standard and indicator lines including of seven sources of resistance to SCN most commonly used by the soybean genetic breeding programs in the United States of America (Niblack et al., 2002) plus 'Hartwig' (Dias et al., 2009). Lines can be added in the HG-type characterization used as resistance sources in other breeding programs (Niblack et al., 2002). This is a great advantage because the genetic make-up of the nematode population can be

Table 1 - Characterization of the Heterodera glycines type (HG-type) present in the sample from the Nematode Bank of the Soybean Genetic Breeding Program at the Universidade Federal de Viçosa, under greenhouse conditions, Viçosa, MG, 20091

\begin{tabular}{|c|c|c|c|c|c|c|c|c|c|}
\hline & \multicolumn{9}{|c|}{ differentiator lines } \\
\hline & $\underset{\Xi}{\stackrel{\Xi}{\triangle}}$ & مِ & $\begin{array}{l}\infty \\
\infty \\
\infty \\
\infty \\
\frac{\infty}{\alpha}\end{array}$ & $\begin{array}{l}\text { no } \\
\frac{0}{2} \\
\frac{8}{2}\end{array}$ & 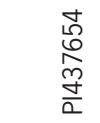 & 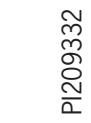 & $\begin{array}{l}\stackrel{N}{N} \\
\frac{\infty}{\alpha}\end{array}$ & $\begin{array}{l}\omega \\
\stackrel{1}{1} \\
\infty \\
\frac{\infty}{\sim} \\
\frac{1}{\alpha}\end{array}$ & $\frac{\sum_{\frac{1}{3}}^{0}}{\frac{1}{1}}$ \\
\hline & & 1 & 2 & 3 & 4 & 5 & 6 & 7 & 8 \\
\hline Number of female ${ }^{2}$ & 348.0 & 6.5 & 3.8 & 6.5 & 2.8 & 6.0 & 5.3 & 14.8 & 0.0 \\
\hline Female Index ${ }^{3}$ & & $1.9(-)$ & $1.1(-)$ & $1.9(-)$ & $0.8(-)$ & $1.7(-)$ & $1.5(-)$ & $4.2(-)$ & $0.0(-)$ \\
\hline HG Type & & & & & 0 (zero) & & & & \\
\hline
\end{tabular}

${ }^{1} \mathrm{HG}$-type characterization according to Niblack et al. (2002); ${ }^{2}$ Number of replications: $\mathrm{n}=6$; and

${ }^{3}$ Female Index $(I F)=\left(\frac{\text { Mean of the number of females in the genotype under testing }}{\text { Mean number of females in 'Lee } 74 \text { ' }}\right) \times 100$, where: (IF) $<10 \%=(-)$ and IF $\geq 10 \%=(+)$. 
more thoroughly characterized for resistance to $\mathrm{SCN}$. Furthermore, the test gives information on the potential of the population to adapt or respond to selection pressure resulting in loss of effectiveness of resistance. The nematode population present in the NBSGBP-UFV sample did not multiply in any of the eight indicator lines so these sources could therefore be used as SCN resistance sources in breeding programs whose cropping area present $H$. glycines population similar to the NBSGBP-UFV.

Lee 74 cultivar supported the greatest mean number of females (348.0), followed by the group formed by 'Pickett' and PI 548316. There was a greater egg production in 'Lee 74' than PI 88788, PI 90763, PI 437654, PI 209332, and 'Hartwig' which had the smallest egg production. Moreover, 'Lee 74' also differed ( $p \leq 0.05$ ) from Pickett, Peking, PI 89772, and PI 548316 in egg number. The reproduction factor ranged from 0.00 in 'Hartwig' to 8.02 in 'Lee 74 ' (Table 2).

Table 2 - Mean number of females (NF), eggs (EN), reproduction factor (RF), plant height (PH), number of nodes (NN), fresh matter weight (FMW) and dry matter weight (DMW) of 10 Heterodera glycines differentiating lines artificially inoculated under greenhouse conditions, Viçosa, MG, $2009^{1}$

\begin{tabular}{|c|c|c|c|c|}
\hline \multirow{2}{*}{ Differentiator lines } & \multicolumn{4}{|c|}{ Traits related to resistance } \\
\hline & $\mathrm{NF}^{2}$ & \multicolumn{2}{|c|}{$\mathrm{EN}^{2}$} & $\mathrm{RF}^{3}$ \\
\hline Lee 74 & $18.44 \mathrm{a}$ & \multicolumn{2}{|c|}{$171.84 \mathrm{a}$} & 8.02 \\
\hline Pickett & $4.64 \mathrm{~b}$ & \multicolumn{2}{|c|}{$55.18 b$} & 0.89 \\
\hline Peking & $2.60 \mathrm{c}$ & \multicolumn{2}{|c|}{$31.08 b$} & 0.29 \\
\hline PI88788 & $1.82 \mathrm{c}$ & \multicolumn{2}{|c|}{$11.11 \mathrm{c}$} & 0.09 \\
\hline PI90763 & $2.48 \mathrm{c}$ & \multicolumn{2}{|c|}{$6.36 c$} & 0.05 \\
\hline PI437654 & $1.60 \mathrm{c}$ & \multicolumn{2}{|c|}{$11.12 \mathrm{c}$} & 0.09 \\
\hline PI209332 & $2.31 \mathrm{c}$ & \multicolumn{2}{|c|}{$22.56 \mathrm{c}$} & 0.20 \\
\hline PI89772 & $2.28 \mathrm{c}$ & \multicolumn{2}{|c|}{$29.53 b$} & 0.26 \\
\hline PI548316 & $3.82 b$ & \multicolumn{2}{|c|}{$35.94 b$} & 0.43 \\
\hline Hartwig & $0.71 \mathrm{c}$ & \multicolumn{2}{|c|}{$0.71 \mathrm{c}$} & 0.00 \\
\hline CV (\%) & 33.19 & \multicolumn{2}{|c|}{64.03} & \\
\hline \multirow{2}{*}{ Differentiator lines } & \multicolumn{4}{|c|}{ Agronomic traits } \\
\hline & $\mathrm{PH}$ & NN & FMW & DMW \\
\hline & $\mathrm{cm}$ & & & $g$ \\
\hline Lee 74 & $114.50 \mathrm{a}$ & $11.33 \mathrm{a}$ & $17.92 \mathrm{a}$ & $3.43 \mathrm{a}$ \\
\hline Pickett & $95.30 \mathrm{a}$ & $11.00 \mathrm{a}$ & $13.85 \mathrm{a}$ & $2.89 a$ \\
\hline Peking & $38.92 \mathrm{c}$ & $9.00 \mathrm{c}$ & 15.07 a & $2.94 \mathrm{a}$ \\
\hline PI88788 & $103.58 \mathrm{a}$ & $10.50 \mathrm{~b}$ & $15.79 a$ & $2.92 \mathrm{a}$ \\
\hline PI90763 & $68.50 \mathrm{~b}$ & $9.67 \mathrm{c}$ & $11.86 \mathrm{~b}$ & $2.48 b$ \\
\hline PI437654 & $77.83 b$ & $9.00 \mathrm{c}$ & $9.30 \mathrm{~b}$ & $1.69 \mathrm{~b}$ \\
\hline PI209332 & $86.00 \mathrm{a}$ & $10.33 b$ & $11.75 \mathrm{~b}$ & $2.33 b$ \\
\hline PI89772 & $96.75 \mathrm{a}$ & $9.33 c$ & $14.28 a$ & $2.97 \mathrm{a}$ \\
\hline PI548316 & $61.25 b$ & $9.00 \mathrm{c}$ & $10.58 b$ & $2.18 b$ \\
\hline Hartwig & $71.75 b$ & $11.33 \mathrm{a}$ & $16.63 \mathrm{a}$ & $2.78 \mathrm{a}$ \\
\hline CV (\%) & 20.86 & 6.23 & 25.98 & 27.25 \\
\hline
\end{tabular}

${ }^{1}$ Means followed by the same letter in the column formed a homogenous group by the Scott-Knott grouping method $(p<0.05)$; ${ }^{2}$ Original values transformed in $\sqrt{(x+1)}$; and ${ }^{3}$ Reproduction factor (RF) according to Oostenbrink (1966).
Among the agronomic characteristics, the plant height in 'Peking' had the lowest mean $(38.92 \mathrm{~cm})$ and was different $(p \leq 0.05)$ from the other groups. 'Lee 74 ', 'Pickett', PI 88788, PI 209332, and PI 89772 formed a group with means ranging from $86-114.5 \mathrm{~cm}$. 'Lee 74 ', 'Pickett', and 'Hartwig' formed the group with the highest means for number of nodes while the group with the lowest means was formed by 'Peking', PI 90763, PI 437654, PI 89772, and PI 548316. Similar performance was observed in the differentiating lines for the fresh and dry matter weights, where 'Lee 74 ', 'Pickett', 'Peking', PI 88788, PI 89772, and 'Hartwig' formed the group with the highest means (Table 2).

'Lee 74 ' was the most dissimilar (100 \% dissimilarity) compared to the other genotypes, relative to the traits related to SCN resistance (Figure 1A). 'Peking', 'Pickett', PI 88788, PI 90763, PI 437654, PI 209332, PI 89772, PI 548316, and 'Hartwig' were similar, at the magnitude of $<10 \%$. Among these, the most similar were PI 88788 and PI 437654, followed by 'Peking', PI 89773 , and PI 209332. When only the agronomic traits were considered (Figure 1B) there was greater dissimilarity among the differentiating lines. Three pairs presented dissimilarity less than $10 \%$, namely 'Pickett' and PI 209332, PI 90763 and PI 548316, and 'Lee74' and PI 88788. 'Hartwig' was the most dissimilar (100 \%) among those assessed and 'Peking' presented $90 \%$ dissimilarity in relation to the other hosts. When the dendrogram was analyzed that considered all the traits assessed (Figure 1C) the most dissimilar performance was observed in 'Lee 74' (100 \%) followed by 'Hartwig' (> $10 \%$ and < $20 \%$ dissimilarity). The other genotypes presented less than $10 \%$ dissimilarity.

The first two eigenvalues explained at least $88 \%$ of the total variation. Using the canonic variables for traits related to resistance (Figure 2A), 'Lee 74' was the most distant graphically and had greatest divergence among the differentiating lines. 'Pickett' and 'Hartwig' were the most divergent of the remaining differentials, followed by PI 548316 and 'Hartwig'. When all traits were considered similar performance was observed from 'Lee 74' (Figure 2C) and 'Hartwig' was the most divergent. A different result among the differentiating lines is presented in Figure 2B that considered when the agronomic traits were considered alone, they diverged more amongst each other, except for 'Hartwig' and 'Peking' that presented greater graphic distance. In the grouping analysis, only two groups formed in Figure 1A and 1C. In group I nine differentiating lines (90\% of the genotypes assessed) and in group II, 'Lee 74' were seen. In Figure 2B, four groups formed: group I formed by 'Lee 74', 'Pickett', PI 88788, PI 90763, PI 437654, PI 209332, and PI 548316 that represented $70 \%$ of the genotypes assessed, group II by PI 89772, group III by 'Hartwig' and group IV by 'Peking', each represented by $10 \%$ of the genotypes.

Using resistance sources in the development of high-yielding disease resistant soybean cultivars has been one of the main objectives of many soybean breed- 


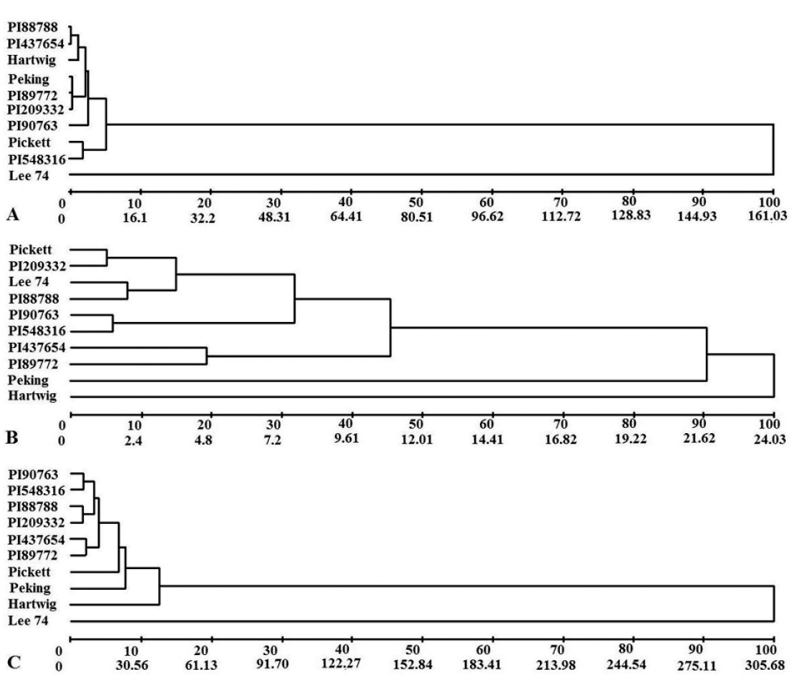

Figure 1 - Dendrograms illustrating the dissimilarity among soybean cyst nematode differentiating lines obtained by the UPGMA (Unweighted Pair Group Method with Arithmetic Mean) method, based on the Mahalanobis distance, considering (A) the traits related to resistance, $(B)$ the agronomic traits and $(C)$ all the traits assessed in the experiment. Vicosa, MG, 2009.

ing programs. The development of effective SCN-resistant cultivars is one of the greatest contributions of plant breeding (Sediyama et al. (2009). The improved cultivars carry genes that can express high yield, wide adaptation and good resistance/tolerance to biotic or abiotic factors (EMBRAPA, 2008). In addition, desirable agronomic traits have also been considered by geneticists and breeders.

About 50 resistant soybean cultivars are available to Brazilian producers and annually new cultivars are presented on the market. The most used strategy to incorporate SCN resistance is line selection from populations derived from hybridizations among adapted genotypes and North American resistant cultivars (Dias et al., 2009). The success of a breeding program lies in the existence of genetic variability in the working population, that is, breeders have recommended intercrossing among superior and divergent cultivars to form the base population (Cruz and Carneiro, 2006). With this, 'Hartwig', 'Peking', PI 437654, and PI 89772 appear to be good options as parents because they present resistance to SCN, genetic divergence compared to the other differentiating lines based on the agronomic traits, and they present many desirable agronomic traits. The progenies developed by hybridization from these resistance sources with susceptible cultivars could present different resistance genes. Young (1982), Luedders (1983) and Young (1994) stressed the importance of rotating cultivars with different resistance sources in nematode management. Cultivar rotation can be important to prevent cultivar yield suppression and the practice should be accompanied to maintain the SCN population density below the economic threshold (Young, 1994).
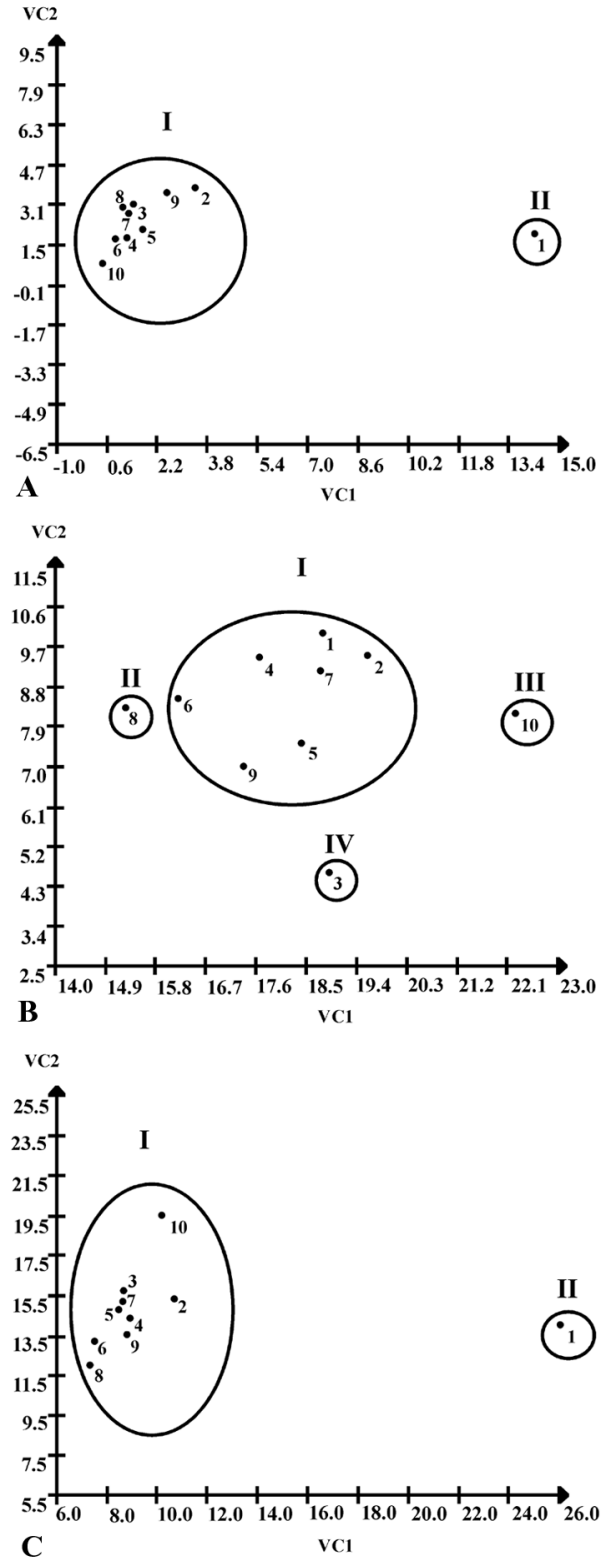

Figure 2 - Differentiating lines graphic dispersion (1-'Lee 74'; 2-'Peking', 3-'Peking', 4-PI 88788, 5-PI 90763, 6-PI 437654, 7-PI 209332, 8-PI 89772, 9-PI 548316, 10-'Hartwig'), based on the first two canonic variables (VC1 and VC2) for (A) the traits related to resistance, $(\mathrm{B})$ the agronomic traits and $(\mathrm{C})$ all the traits assessed in the experiment. The differentiating lines were grouped by the Tocher optimization method, Viçosa, MG, 2009.

After incorporating resistance, the recently released cultivars in Brazil substituted the North American cultivars as resistance sources (Dias et al., 2009) because they present both agronomic adaptations to Brazilian cropping conditions and SCN resistance. Although nematode resistance is generally identified and characterized based on nematode reproduction inhibition, the main objective for the development of resistance is protection of the crop yield. Releasing a resistant, but little productive, cultivar 
will probably not meet the producers requirements (Starr and Roberts, 2004). Resistance can be considered an advance in the genetic quality of the cultivar, which may contribute to maintaining or increasing yield.

\section{Acknowledgments}

To the Conselho Nacional de Desenvolvimento Científico e Tecnológico (CNPq-Brazil) for financial support in carrying out this study (MSc and research productivity grants).

\section{References}

Conde, A.B.T.; Coelho, M.A.O.; Fronza, V.; Souza, L.V. 2011. Genetic divergence in rainfed wheat based on morphoagronomic traits. Revista Ceres 57: 762-767 (in Portuguese, with abstract in English).

Cruz, C.D. 2006. Genes Software: Statistical Experimental and Arrays. UFV Press, Viçosa, MG, Brazil (in Portuguese).

Cruz, C.D.; Carneiro, P.C.S. 2006. Biometric Models Applied to Genetic Breeding. 2ed. UFV Press, Viçosa, MG, Brazil (in Portuguese).

Cruz, C.D. 2008. Genes Software: Genetic Diversity. UFV Press, Viçosa, MG, Brazil (in Portuguese).

Dhingra, O.D.; Mendonça, H.L.; Macedo, D.M. 2009. Diseases and their control. p. 133-155. In: Sediyama, T., ed. Production technologies and uses of soybean. Mecenas Press, Londrina, PR, Brazil (in Portuguese).

Dias, W.P.; Silva, J.F.V.; Carneiro, G.E.S.; Garcia, A.; Arias, C.A.A. 2009. Soybean cyst nematode: biology and management through genetic resistance. Nematologia Brasileira 33: 1-16 (in Portuguese, with abstract in English).

Dias, W.P.; Silva, J.F.V.; Kiihl, R.A.S.; Hiromoto, D.M.; Abdelnoor, R.V. 1998. Resistance break of Hartwig cultivar by field population of the soybean cyst nematode (Heterodera glycines). Pesquisa Agropecuária Brasileira 33: 971-973 (in Portuguese, with abstract in English).

Empresa Brasileira de Pesquisa Agropecuária [EMBRAPA]. 2008. Soybean Production Technologies: The Central Region of Brazil; 2009 and 2010. Embrapa, Londrina, PR, Brazil (in Portuguese).

Fehr, W.R.; Caviness, C.E. 1977. Stages of soybean development. Iowa State University of Science and Technology. Ames, IA, USA. (Special Report 80).

Leão, P.C.S.; Cruz, C.D.; Motoike, S.Y. 2011. Genetic diversity of table grape based on morphoagronomic traits. Scientia Agricola 68: 42-49.

Lima, R.D.; Ferraz, S.; Santos, J.M. 1992. Occurrence of Heterodera sp. on soybean at the Triangulo Mineiro. Nematologia Brasileira 16: 101-101 (in Portuguese).

Lordello, A.I.L.; Lordello, R.R.A.; Quaggio, J.A. 1992. Occurrence of Heterodera glycines on soybean in Brazil. Revista de Agricultura 67: 223-225 (in Portuguese, with abstract in English).

Luedders, V.D. 1983. Genetics of the cyst nematode-soybean symbiosis. Phytopathology 73: 944-948.

Matsuo, E.; Sediyama, T.; Cruz, C.D.; Silva, A.A.; Oliveira, R.C.T.; Nogueira, A.P.O.; Tancredi, F.D. 2009. Resistance of soybean genotypes to glyphosate. Planta Daninha 27: 1063-1073 (in Portuguese, with abstract in English).
Monteiro, A.R.; Moraes, S.R.A.C. 1992. Occurrence of soybean cyst nematode, Heterodera glycines Ichinohe, 1952, damaging the culture at Mato Grosso do Sul. Nematologia Brasileira 16: 101-101 (in Portuguese).

Niblack, T.L.; Arelli, P.R.; Noel, G.R.; Opperman, C.H.; Orf, J.H.; Schmitt, D.P.; Shannon, J.F.; Tylka, G.L. 2002. A revised classification scheme for genetically diverse populations of Heterodera glycines. Journal of Nematology 34: 179-288.

Niblack, T.L.; Lambert, K.N.; Tylka, G.L. 2006. A model plant pathogen from the kingdom animalia: Heterodera glycines the soybean cyst nematode. Annual Review of Phytopathology 44: 283-303.

Oostenbrink, M. 1966. Major characteristics of the relation between nematodes and plant. Mededelingen Landbouwhogeschool Wageningen 66: 1-46.

Riggs, R.D.; Schmitt, D.P. 1988. Complete characterization of the race scheme for Heterodera glycines. Journal of Nematology 20: 392-395.

Santana, H.; Pires, E.; Comerlato, A.P.; Nasu, E.G.C.; Furlanetto, C. 2009. Genetic variability in field populations of the soybean cyst nematode from the States of Paraná and Rio Grande do Sul, Brazil. Tropical Plant Pathology 34: 261-264 (in Portuguese, with abstract in English).

Schmitt, D.P.; Noel, G.R. 1984. Nematodes parasites of soybean. p. 13-59. In: Nickle, W.R., ed. Plant and insect nematode. Marcel Dekker, New York, NY, USA.

Sediyama, T.; Teixeira, R.C.; Barros, H.B. 2009. Cultivars. p. 7791. In: Sediyama, T., ed. Production technologies and uses of soybean. Mecenas Press, Londrina, PR, Brazil (in Portuguese).

Silva, J.A.L.; Sediyama, T.; Cecon, P.R. 1999a. Evaluation of 22 American and Brazilian soybean cultivars and lines to Heterodera glycines, race 3. Nematologia Brasileira 23: 15-19 (in Portuguese, with abstract in English).

Silva, J.A.L.; Sediyama, T.; Teixeira, R.C. 1999b. Reaction of soybean cultivars and lines to Heterodera glycines, race 3. Revista Ceres 46: 99-104 (in Portuguese, with abstract in English).

Silva, J.A.L.; Sediyama, T.; Teixeira, R.C.; Oliveira, R.D.L. 1999c. Physiologic races of soybean cyst nematode, Heterodera glycines, in the State of Goiás, Mato Grosso, Mato Grosso do Sul and Minas Gerais. Revista Ceres 46: 45-52 (in Portuguese, with abstract in English).

Starr, J.L.; Roberts, P.A. 2004. Resistance to plant-parasitic nematodes. p. 879-907. In: Chen, Z.X.; Chen, S.Y.; Dickson, D.W., eds. Nematology: advances and perspectives. CAB International, Wallingford, UK.

Triantaphyllou, A.C. 1975. Oogenesis and the chromosomes of twelve bisexual species of Heterodera (Nematoda: Heteroderidae). Journal of Nematology 7: 34-40.

Triantaphyllou, A.C.; Esbenshade, P.R. 1990. Demonstration of multiple mating in Heterodera glycines with biochemical markers. Journal of Nematology 22: 452-456.

Young, L.D. 1982. Reproductions of differentially selected soybean cyst nematode populations on soybean. Crop Science 22: $385-388$.

Young, L.D. 1994. Changes in reproduction of a Heterodera glycines race 5 isolate cultured on 'Cordell' and 'Bedford' soybean. Journal of Nematology 26: 653-655. 